\title{
Modeling conifer tree crown radius and estimating canopy cover
}

\author{
Samantha J. Gill , Gregory S. Biging ，Edward C. Murphy
}

\begin{abstract}
Models of tree crown radius were developed for several conifer species of California. Typical forest inventory variables (DBH, height, height to crown base, crown class, basal area per hectare, and trees per hectare) were considered as independent variables in model development. Models were fitted using both ordinary and weighted least squares methods. It was found that for the species studied, an ordinary least squares linear regression with DBH as the only independent variable was appropriate. For some species studied, the addition of other independent variables provided minor improvements over the model with only DBH. These models of crown radius could be summed to give an estimation of canopy cover. Using crown mapped data, it was possible to test and calibrate these models to predict non overlapping canopy cover. Linear and non linear models were considered for calibration. A non linear model with an upper asymptote seemed to be the best calibration. These models enable an efficient and unbiased method of estimation of canopy cover as an alternative to photointerpretation estimation of cover.
\end{abstract}

\section{Introduction}

Most standard forest inventories include individual tree diameters and species as primary variates. Height may be subsampled, and in rare instances, crown radius is subsampled. However, in general, crown radius is not typically measured. Crown radius is needed in certain kinds of competition measures (see Daniels et al., 1986; Biging and Dobbertin, 1992, 1995) and in determining canopy cover, and so it is logical to predict crown radius from the inventory data. In this paper, we developed crown radius models for the major conifer species of northern California and validated their use in predicting canopy cover.

Canopy cover (Avery and Burkart, 1994) is defined as the percent forest area occupied by the vertical projection of tree crowns. It is also referred to as crown closure, crown cover and canopy closure. Throughout 
this paper, we use the term canopy cover because it is frequently used in the literature on this subject. Canopy cover is commonly used as a measure of stand density and is often used as an important indicator of wildlife habitat. Canopy cover data can also be used for predicting woody plant composition, tree volume, or potential forage production, and for the evaluation of forest pest damage (O'Brien, 1989). The three parameters used in the California Wildlife Habitat Relationship (CWHR) classes (Mayer and Laudenslayer, 1988) are canopy cover, species composition, and quadratic mean diameter. Since CWHR classes are now used commonly in California, and other similar classification systems are used in other parts of the US, reliable estimates of these parameters are essential. We focused on canopy cover because the other parameters can be estimated with standard forest inventory data.

\section{Measuring canopy cover}

The definition of canopy cover is one that is derived from the aerial photointerpretation literature (cf. Paine, 1981). Canopy cover is the summation of crown areas as seen from above the canopy. The individual crown areas seen from above are not of the entire crown. Rather a photointerpreter sees that portion of the crown which extends above the intersection with its neighbors. Clearly, there can be additional crown extending deeper into the canopy that the photointerpreter cannot see. This means that the estimates (or measurements) that a photointerpreter makes for canopy cover are unavoidably different from the measurements taken in the field.

Field and photographic methods for estimating canopy cover include stem and crown mapping, line intercept transects, visual estimation, moosehorns, and densiometers. Of these methods, stem and crown mapping is probably the most accurate, but it is expensive. Visual estimation is simple, but often biased. Densiometers are relatively simple to use, but biased (Cook et al., 1995). Densiometers and moosehorns are inconsistent among observers (Vales and Bunnell, 1988). Line intercept transects are relatively easy to apply, but the amount of transects needed to accurately estimate canopy cover is not fully established (O'Brien, 1989; Congalton and
Biging, 1992). The most prevalent method for estimating canopy cover is through aerial photointerpretation (Avery and Burkart, 1994). However, Biging et al. (1991) have found photointerpreted estimates of canopy cover to be less accurate than commonly believed. Another photographic technique that is employed sometimes is the use of hemispherical photographs. Bunnel and Vales (1989) compared several methods, including hemispherical photographs, ocular methods, densiometers, and moosehorn and found that there were strong effects of technique on the estimate of canopy cover. They found that narrow angles of view did a better job of estimating canopy cover and that vertical projection of crowns was the least biased.

An alternative to field methods is to apply a crown radius model to an inventory tree list to predict average crown radius, then sum the estimates, and divide by unit area to predict canopy cover. Rather than predicting average crown radius, some researchers have predicted maximum ${ }^{3}$ crown radius (Paine and Hann, 1982; Farr et al., 1989; Warbington and Levitan, 1992; Goelz, 1996; Uzoh and Ritchie, 1996). The maximum crown radius approach overpredicted tree and hence canopy cover, so an adjustment to the estimates is necessary (Warbington and Levitan, 1992). This adjustment was based on the overlap of circles expected from a Poisson process (Serra, 1982).

A different approach proposed in this study was to use regression equations to calibrate the canopy cover derived from summing the predicted individual tree crown areas with non-overlapping canopy cover. Direct measurements of canopy cover were used in the calibrations.

\section{Objectives}

The objective of this project was to develop predictive models of crown radius that would be useful in numerous forest management applications, including the prediction of canopy cover. To accomplish this objective, models of crown radius for each species were developed using forest inventory tree data as independent variables. By summing the predicted

\footnotetext{
${ }^{3}$ Maximum crown radius is defined either as the crown radius of open grown trees, or the longest live branch of forest trees.
} 
crown areas and dividing by unit area, an estimate of canopy cover was obtained. A subobjective was to test and calibrate these models for use in canopy cover estimation.

\section{Data}

Data for this project comprised forest inventory data for Sierra Pacific Industries (SPI) properties in California, and were supplemented with additional test data. SPI landholdings include over 400000 hectares of forestland which span from the west of the Yosemite National Park to the Oregon/California border and across to the coastline. The SAF forest types and number (in parenthesis) represented include Red Fir (207), White Fir (211), Pacific Douglas-fir (229), Redwood (232), Douglas-fir Tanoak Pacific Madrone (234), Sierra Nevada Mixed Conifer (243), Pacific Ponderosa Pine Douglas-fir (244), Pacific Ponderosa Pine (245), Jeffrey Pine (247), and Blue Oak-Digger Pine (250) (Eyre, 1980). Throughout this range, there is a wide diversity of species, tree sizes, and canopy cover.

The main data, referred to as CR data, were taken using variable radius plots (BAF factors 20 or $40 \mathrm{ft}^{2} /$ acre $\left(4.6\right.$ or $\left.9.2 \mathrm{~m}^{2} / \mathrm{ha}\right)$ ) established on a four by 10 chain $(80.5 \mathrm{~m}$ by $201.2 \mathrm{~m}$ ) grid on the SPI landholdings. Every tree on the plot was measured for DBH (nearest $0.25 \mathrm{~cm}, 0.1 \mathrm{in}$ ), number of logs, crown ratio and crown class (dominant, codominant, intermediate and suppressed). On each plot, the first and third conifer trees from the north were also measured for total tree height (nearest $0.3 \mathrm{~m}, 1 \mathrm{ft}$ ), height-to-crown base $(0.3 \mathrm{~m}, 1 \mathrm{ft})$ and two crown radii measurements (nearest $0.3 \mathrm{~m}, 1 \mathrm{ft}$ ). The crown radii measured were the crown radius towards the center of the plot and a crown radius perpendicular to that measurement. In the field, we measured non-overlapping canopy cover to make these two measures correspond as closely as possible to what would have been measured using photointerpretation. Thus, the crown radii measured are not necessarily the full extent of the crown. The field observer estimated the point, as seen from above, where the subject tree and the adjacent neighbor crown intersected. This point lies on the chord formed by the intersections of the two crown surfaces (see Fig. 1). This point was projected downwards to the tape measure by alignment of the observer and the intersect point by use of a clinometer with a vertical tic mark.

The CR data set contains 61635 trees with crown radii (refer to Tables 14 ) measured to the nearest $0.3 \mathrm{~m}(1 \mathrm{ft})$. This data set contained more than 13 species of conifers: Douglas-fir (Pseudotsuga menziesii (Mirb.) Franco), incense cedar (Calecedrus decurrens (Torr.)), lodgepole pine (Pinus contorta Douglas.), ponderosa pine (Pinus ponderosa Laws.), red fir (Abies magnifica A. murr), redwood (Sequoia sempervirens (D. Don) Endl), sugar pine (Pinus Lambertiana Dougl.), white fir (Abies concolor Lindl. and Gord.) western hemlock (Tsuga heterohylla Sarg.),

Table 1

Descriptive statistics for CR fitted data: means and standard deviations

\begin{tabular}{|c|c|c|c|c|c|c|c|c|c|c|c|}
\hline \multirow[t]{2}{*}{ Species } & \multirow[t]{2}{*}{$\begin{array}{l}\text { No. of } \\
\text { trees }\end{array}$} & \multicolumn{2}{|c|}{$\mathrm{DBH}(\mathrm{cm})$} & \multicolumn{2}{|c|}{ Total height (m) } & \multicolumn{2}{|c|}{$\begin{array}{l}\text { Height to crown } \\
\text { base }(\mathrm{hcb})(\mathrm{m})\end{array}$} & \multicolumn{2}{|c|}{$\begin{array}{l}\text { Stand basal } \\
\text { area }\left(\mathrm{m}^{2} / \mathrm{ha}\right)\end{array}$} & \multicolumn{2}{|c|}{$\begin{array}{l}\text { Crown } \\
\text { radius (m) }\end{array}$} \\
\hline & & mean & s.d. & mean & s.d. & mean & s.d. & mean & s.d. & mean & s.d. \\
\hline Douglas fir & 13082 & 53.1 & 26.2 & 28.2 & 6.1 & 11.9 & 6.1 & 45.7 & 25.0 & 3.5 & 1.3 \\
\hline Incense cedar & 3427 & 53.1 & 23.9 & 21.1 & 7.9 & 9.2 & 4.8 & 44.9 & 25.9 & 2.7 & 0.9 \\
\hline Lodgepole pine & 117 & 38.1 & 13.5 & 21.3 & 6.0 & 10.0 & 5.5 & 44.2 & 22.7 & 2.2 & 0.9 \\
\hline 'Other conifers' & 120 & 59.9 & 25.9 & 25.0 & 8.4 & 9.3 & 5.1 & 54.8 & 30.6 & 2.8 & 1.3 \\
\hline Old growth & 271 & 125.5 & 28.2 & 48.1 & 9.4 & 20.2 & 8.3 & 48.9 & 25.9 & 5.5 & 1.6 \\
\hline Ponderosa pine & 4588 & 51.6 & 21.3 & 26.4 & 9.6 & 11.8 & 5.9 & 38.4 & 23.8 & 2.8 & 1.0 \\
\hline Red fir & 1315 & 58.9 & 24.6 & 27.6 & 9.8 & 12.6 & 7.0 & 51.9 & 32.4 & 2.5 & 0.9 \\
\hline Redwood & 703 & 58.9 & 23.4 & 28.2 & 9.1 & 14.3 & 7.4 & 54.5 & 36.7 & 3.6 & 1.2 \\
\hline Sugar pine & 2860 & 148.3 & 24.9 & 27.1 & 9.6 & 12.3 & 6.4 & 43.0 & 26.6 & 3.3 & 1.3 \\
\hline White fir & 10481 & 47.5 & 18.0 & 25.1 & 7.9 & 10.6 & 5.6 & 49.5 & 28.3 & 2.7 & 0.8 \\
\hline All trees & 36964 & 60.5 & 23.1 & 27.8 & 8.4 & 12.2 & 6.2 & 47.6 & 27.8 & 3.2 & 1.1 \\
\hline
\end{tabular}




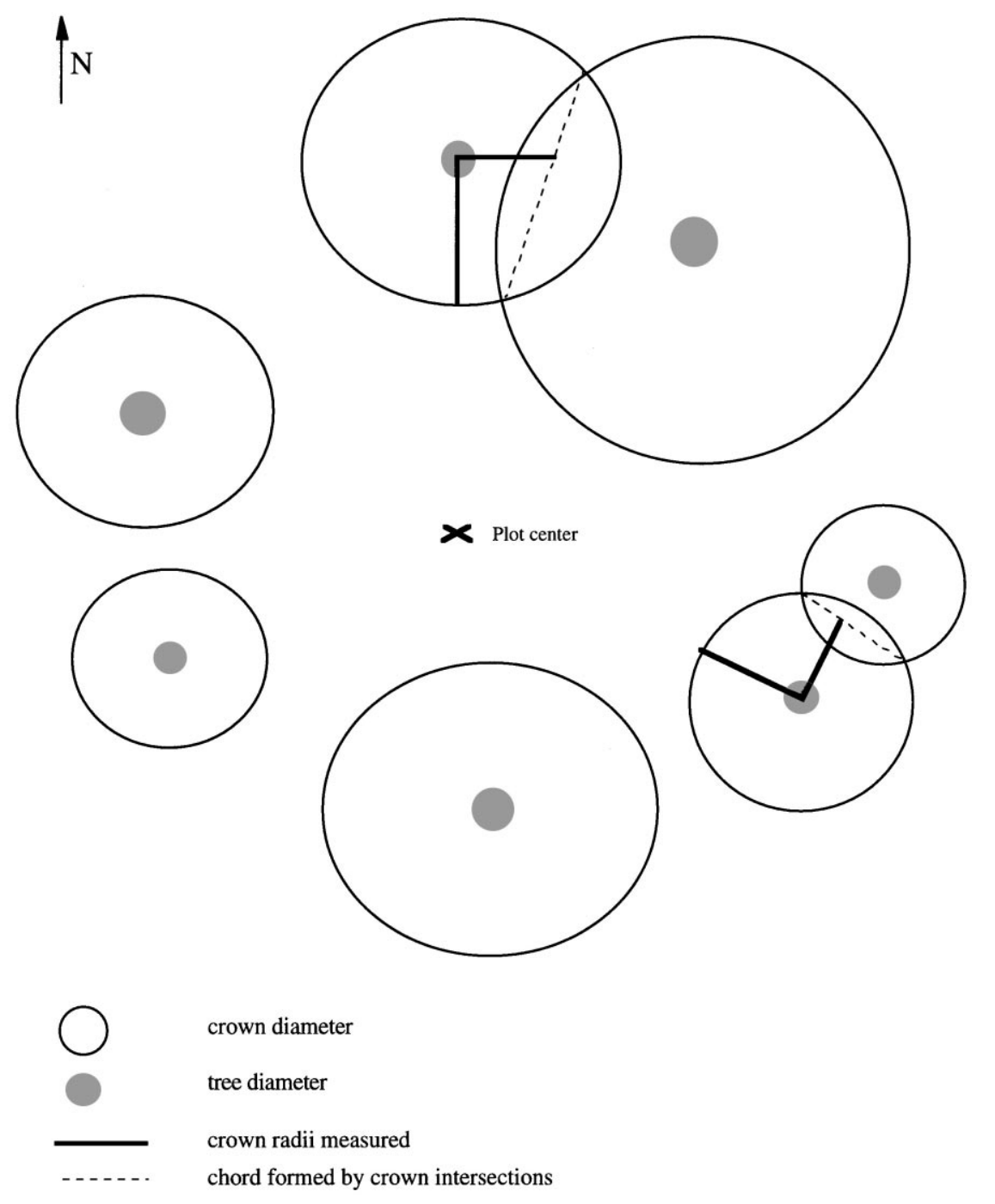

Fig. 1. An example of the crown radii that would be measured on a plot.

sitka spruce (Picea sitchensis (Bong.) Carr), port orford cedar (Chamaecyparis lawsonia (A. Murr.)), western white pine (Pinus monticola D. Don), and knobcone pine (Pinus attenuata Lemm.). On account of limited data, for modeling purposes, western hemlock, sitka spruce, port orford cedar, western white pine, and knobcone pine were combined into a species group named 'other conifers'. A wide range of tree sizes and stand densities were measured (refer to Tables 14 ).

On account of the size of this data set, it was possible to divide the data into a model and a test data set (Burk, 1990). Sixty percent of the data was randomly selected and used for model fitting and the remaining $40 \%$ used for testing. We refer to the fitted data set for modeling crown radii as CR fitted data and the test data set as CR test. Refer to Tables 14 for descriptive statistics for each of these divisions of the data. The means and ranges of these data sets are similar for each of the variables studied.

An independent data set used in other studies (Biging et al., 1991), referred to as cover data, was used as a second test data set. This data consisted of 6770.04 ha (1/10 acre) circular plots for a total of 
Table 2

Descriptive statistics for CR fitted data: minimums and maximums

\begin{tabular}{|c|c|c|c|c|c|c|c|c|c|c|}
\hline \multirow[t]{2}{*}{ Species } & \multicolumn{2}{|c|}{$\mathrm{DBH}(\mathrm{cm})$} & \multicolumn{2}{|c|}{ Total height (m) } & \multicolumn{2}{|c|}{$\begin{array}{l}\text { Height to crown } \\
\text { base (hcb) (m) }\end{array}$} & \multicolumn{2}{|c|}{$\begin{array}{l}\text { Stand basal } \\
\text { area }\left(\mathrm{m}^{2} / \mathrm{ha}\right)\end{array}$} & \multicolumn{2}{|c|}{$\begin{array}{l}\text { Crown } \\
\text { radius (m) }\end{array}$} \\
\hline & $\min$. & $\max$ & $\min$. & $\max$. & $\min$. & $\max$. & $\min$. & $\max .^{a}$ & $\min$. & $\max$. \\
\hline Douglas fir & 7.6 & 231.1 & 6.1 & 78.0 & 0.3 & 51.5 & 4.6 & 192.8 & 0.3 & 10.1 \\
\hline Incense cedar & 12.7 & 177.8 & 4.9 & 63.4 & 0.6 & 39.6 & 4.6 & 183.6 & 0.6 & 8.2 \\
\hline Lodgepole pine & 22.9 & 104.1 & 9.4 & 42.7 & 1.5 & 23.5 & 9.2 & 119.3 & 0.6 & 4.9 \\
\hline 'Other conifers' & 22.9 & 142.2 & 8.2 & 46.0 & 0.9 & 26.5 & 9.2 & 146.9 & 0.9 & 6.4 \\
\hline Old growth & 45.7 & 231.1 & 26.5 & 79.2 & 5.5 & 54.9 & 4.6 & 146.9 & 1.5 & 10.7 \\
\hline Ponderosa pine & 12.7 & 203.2 & 5.5 & 65.2 & 0.3 & 52.4 & 4.6 & 146.9 & 0.3 & 8.8 \\
\hline Red fir & 12.7 & 160.0 & 4.6 & 58.5 & 0.3 & 34.1 & 3.4 & 192.8 & 0.9 & 6.4 \\
\hline Redwood & 10.2 & 157.5 & 5.2 & 55.2 & 0.3 & 43.0 & 4.6 & 257.0 & 0.6 & 8.8 \\
\hline Sugar pine & 12.7 & 218.4 & 7.9 & 78.0 & 0.6 & 41.1 & 4.6 & 192.8 & 0.6 & 8.5 \\
\hline White fir & 5.1 & 170.2 & 4.9 & 63.4 & 0.3 & 41.5 & 4.6 & 202.0 & 0.6 & 9.4 \\
\hline All trees & 5.1 & 231.1 & 4.6 & 79.2 & 0.3 & 54.9 & 3.4 & 257.0 & 0.3 & 10.7 \\
\hline
\end{tabular}

${ }^{a}$ These extreme values represent point densities at selected locations and probably do not represent the overall stand density.

10273 conifer trees (refer to 5 and 6). On these 0.04 ha plots, every tree was measured for DBH, total height, height-to-crown base, and two crown radii measurements. On each tree, two crown radii were measured to the same standards as described under the CR data set. Tree coordinates were measured relative to the plot center. In addition, the species and overstory/understory status of a tree were recorded.

Since tree coordinates as well as two crown radii were measured for the cover data, canopy cover could then be calculated by reconstructing the tree locations and their crowns. After reconstructing the stand to obtain canopy cover, this data set was used to calibrate the canopy cover derived from summing the predicted crown radii. For the canopy cover modeling comparisons, $25 \%$ of the data was reserved for testing. The model data set is referred to as cover model data and the test data as cover test data. The average canopy cover (\%) was 31.08 with a standard deviation of 17.99 and 32.28 with a standard deviation of 18.81 for the cover model and test data sets, respectively.

The CR model data set and CR test have very similar means and ranges for all variables used in this study. The means for the cover data were generally smaller than those for the other two data sets (refer to Tables 1 6).

Table 3

Descriptive statistics for CR test data: means and standard deviations

\begin{tabular}{|c|c|c|c|c|c|c|c|c|c|c|c|}
\hline \multirow[t]{2}{*}{ Species } & \multirow[t]{2}{*}{$\begin{array}{l}\text { No. of } \\
\text { trees }\end{array}$} & \multicolumn{2}{|c|}{ DBH (cm) } & \multicolumn{2}{|c|}{ Total height (m) } & \multicolumn{2}{|c|}{$\begin{array}{l}\text { Height to crown } \\
\text { base (hcb) (m) }\end{array}$} & \multicolumn{2}{|c|}{$\begin{array}{l}\text { Stand basal } \\
\text { area }\left(\mathrm{m}^{2} / \mathrm{ha}\right)\end{array}$} & \multicolumn{2}{|c|}{$\begin{array}{l}\text { Crown } \\
\text { radius (m) }\end{array}$} \\
\hline & & mean & s.d. & mean & s.d. & mean & s.d. & mean & s.d. & mean & s.d. \\
\hline Douglas fir & 8727 & 53.3 & 26.7 & 28.3 & 9.9 & 11.9 & 6.2 & 45.1 & 24.7 & 3.6 & 1.3 \\
\hline Incense cedar & 2290 & 51.8 & 22.9 & 21.0 & 7.7 & 9.1 & 4.7 & 44.7 & 25.7 & 2.6 & 0.9 \\
\hline Lodgepole pine & 76 & 38.6 & 13.0 & 21.7 & 6.2 & 10.1 & 5.6 & 43.1 & 26.1 & 2.2 & 0.8 \\
\hline 'Other conifers' & 78 & 56.9 & 23.4 & 23.6 & 6.9 & 9.0 & 4.3 & 47.9 & 31.1 & 2.5 & 1.0 \\
\hline Old growth & 183 & 124.5 & 26.7 & 48.3 & 10.1 & 20.4 & 7.7 & 46.9 & 23.4 & 5.5 & 1.5 \\
\hline Ponderosa pine & 3125 & 51.8 & 21.1 & 26.2 & 9.4 & 11.6 & 5.8 & 39.1 & 25.2 & 2.8 & 1.0 \\
\hline Red fir & 910 & 58.2 & 23.9 & 27.5 & 10.0 & 12.2 & 7.0 & 50.9 & 31.3 & 2.5 & 0.9 \\
\hline Redwood & 459 & 57.9 & 21.8 & 28.2 & 9.4 & 14.7 & 7.4 & 52.4 & 34.8 & 3.6 & 1.3 \\
\hline Sugar pine & 1929 & 57.7 & 24.1 & 27.4 & 9.3 & 12.3 & 6.2 & 42.4 & 26.2 & 3.3 & 1.3 \\
\hline White fir & 6894 & 47.8 & 18.0 & 25.2 & 7.9 & 10.5 & 5.6 & 48.5 & 27.5 & 2.7 & 0.8 \\
\hline All trees & 24671 & 59.9 & 22.1 & 27.7 & 8.7 & 12.2 & 6.1 & 46.1 & 27.6 & 3.1 & 1.1 \\
\hline
\end{tabular}


Table 4

Descriptive statistics for CR test data: minimums and maximums

\begin{tabular}{|c|c|c|c|c|c|c|c|c|c|c|}
\hline \multirow[t]{2}{*}{ Species } & \multicolumn{2}{|c|}{ DBH (cm) } & \multicolumn{2}{|c|}{ Total height (m) } & \multicolumn{2}{|c|}{$\begin{array}{l}\text { Height to crown } \\
\text { base (hcb) (m) }\end{array}$} & \multicolumn{2}{|c|}{$\begin{array}{l}\text { Stand basal } \\
\text { area }\left(\mathrm{m}^{2} / \mathrm{ha}\right)\end{array}$} & \multicolumn{2}{|c|}{$\begin{array}{l}\text { Crown } \\
\text { radius (m) }\end{array}$} \\
\hline & $\min$. & $\max$. & $\min$. & $\max$. & $\min$. & $\max$. & $\min$. & $\max .^{a}$ & $\min$. & $\max$. \\
\hline Douglas fir & 10.2 & 226.1 & 6.7 & 73.2 & 0.6 & 48.8 & 4.6 & 183.6 & 0.3 & 10.1 \\
\hline Incense cedar & 12.7 & 167.6 & 5.2 & 54.9 & 0.9 & 36.6 & 4.6 & 156.1 & 0.3 & 6.4 \\
\hline Lodgepole pine & 20.3 & 83.8 & 9.4 & 39.6 & 0.6 & 25.6 & 4.6 & 119.3 & 0.9 & 4.3 \\
\hline 'Other conifers' & 20.3 & 127.0 & 10.1 & 47.2 & 0.9 & 22.9 & 4.6 & 146.9 & 0.9 & 5.5 \\
\hline Old growth & 48.3 & 223.5 & 15.8 & 74.4 & 2.1 & 48.8 & 4.6 & 156.1 & 1.5 & 10.4 \\
\hline Ponderosa pine & 12.7 & 172.7 & 4.6 & 63.4 & 0.9 & 36.6 & 2.3 & 192.8 & 0.6 & 7.3 \\
\hline Red fir & 12.7 & 157.5 & 4.9 & 59.1 & 0.3 & 39.6 & 4.6 & 192.8 & 0.6 & 6.7 \\
\hline Redwood & 12.7 & 157.5 & 4.0 & 57.6 & 1.2 & 40.8 & 4.6 & 211.1 & 0.9 & 8.8 \\
\hline Sugar pine & 10.2 & 231.1 & 4.3 & 64.0 & 0.3 & 37.2 & 4.6 & 174.4 & 0.6 & 9.4 \\
\hline White fir & 12.7 & 182.9 & 4.9 & 63.4 & 0.3 & 39.6 & 1.1 & 202.0 & 0.6 & 7.9 \\
\hline All trees & 10.2 & 231.1 & 4.0 & 74.4 & 0.3 & 48.8 & 1.1 & 211.1 & 0.3 & 10.4 \\
\hline
\end{tabular}

${ }^{a}$ These extreme values represent point densities at selected locations and probably do not represent the overall stand density.

\section{Methods}

\subsection{Crown radius}

Since each tree of the CR fitted data set had two crown radius measurements (at right angles to one another), quadratic mean radius $\left(\sqrt{ }\right.$ radius $1^{2}+$ radius $\left.2^{2}\right)$ was used. We considered linear regression models predicting the quadratic mean crown radius as a function of $\mathrm{DBH}, \mathrm{DBH}^{2}$, height-to- crown base, basal area per hectare, and/or elevation on the plot. The models fitted were of the form

$$
\begin{aligned}
\text { crrad } & =b_{0}+b_{1} \mathrm{DBH} \\
\mathrm{crrad} & =b_{0}+b_{1} \mathrm{DBH}+b_{2} \mathrm{DBH}^{2} \\
\mathrm{crad} & =b_{0}+b_{1} \mathrm{DBH}+b_{2} \mathrm{BA} \\
\mathrm{crrad} & =b_{0}+b_{1} \mathrm{DBH}+b_{2} \mathrm{HCB} \\
\mathrm{crrad} & =b_{0}+b_{1} \mathrm{DBH}+b_{2} E
\end{aligned}
$$

\begin{tabular}{|c|c|c|c|c|c|c|c|c|c|c|c|}
\hline \multirow[t]{2}{*}{ Species } & \multirow[t]{2}{*}{$\begin{array}{l}\text { No. of } \\
\text { trees }\end{array}$} & \multicolumn{2}{|c|}{$\mathrm{DBH}(\mathrm{cm})$} & \multicolumn{2}{|c|}{ Total height (m) } & \multicolumn{2}{|c|}{$\begin{array}{l}\text { Height to crown } \\
\text { base (hcb) (m) }\end{array}$} & \multicolumn{2}{|c|}{$\begin{array}{l}\text { Stand basal } \\
\text { area }\left(\mathrm{m}^{2} / \mathrm{ha}\right)\end{array}$} & \multicolumn{2}{|c|}{$\begin{array}{l}\text { Crown } \\
\text { radius (m) }\end{array}$} \\
\hline & & mean & s.d. & mean & s.d. & mean & s.d. & mean & s.d. & mean & s.d. \\
\hline Big leaf maple & 98 & 22.9 & 5.3 & 12.8 & 2.5 & 6.3 & 2.1 & 26.3 & 14.0 & 2.7 & 0.9 \\
\hline Blue oak & 333 & 27.7 & 12.4 & 14.8 & 5.3 & 8.4 & 3.9 & 36.3 & 13.3 & 2.6 & 1.1 \\
\hline Douglas fir & 2898 & 31.0 & 17.0 & 19.9 & 7.9 & 8.9 & 4.7 & 25.3 & 14.7 & 2.5 & 1.0 \\
\hline Incense cedar & 1073 & 29.7 & 16.0 & 14.3 & 6.7 & 7.2 & 4.0 & 31.1 & 16.5 & 1.8 & 0.7 \\
\hline Live oak & 37 & 28.4 & 11.7 & 9.3 & 2.8 & 4.1 & 1.9 & 38.8 & 17.3 & 2.5 & 0.9 \\
\hline Lodgepole pine & 23 & 25.1 & 8.6 & 17.6 & 6.7 & 9.1 & 5.4 & 25.1 & 17.8 & 1.7 & 0.7 \\
\hline 'Other conifers' & 169 & 30.5 & 10.2 & 15.4 & 5.7 & 6.4 & 3.7 & 21.1 & 8.3 & 2.2 & 0.9 \\
\hline 'Other hardwoods' & 16 & 22.1 & 9.4 & 10.9 & 5.3 & 5.6 & 3.1 & 31.0 & 21.6 & 2.5 & 0.9 \\
\hline Ponderosa pine & 688 & 34.0 & 19.1 & 20.8 & 9.8 & 10.3 & 5.9 & 26.4 & 15.0 & 2.0 & 1.0 \\
\hline Red fir & 1638 & 34.0 & 17.5 & 19.5 & 8.7 & 9.0 & 5.3 & 33.8 & 22.4 & 1.9 & 0.7 \\
\hline Sugar pine & 321 & 38.9 & 24.1 & 22.1 & 10.7 & 11.1 & 6.5 & 26.9 & 16.8 & 2.5 & 1.3 \\
\hline White fir & 2979 & 30.7 & 14.2 & 18.4 & 7.4 & 8.0 & 4.9 & 32.6 & 18.4 & 2.0 & 0.7 \\
\hline All trees & 10273 & 29.5 & 14.0 & 16.3 & 6.6 & 7.9 & 4.3 & 29.5 & 17.4 & 2.3 & 0.9 \\
\hline
\end{tabular}

where

Table 5

Descriptive statistics for cover data: mean and standard deviations 
Table 6

Descriptive statistics for cover data: minimums and maximums

\begin{tabular}{|c|c|c|c|c|c|c|c|c|c|c|}
\hline \multirow[t]{2}{*}{ Species } & \multicolumn{2}{|c|}{$\mathrm{DBH}(\mathrm{cm})$} & \multicolumn{2}{|c|}{ Total height (m) } & \multicolumn{2}{|c|}{$\begin{array}{l}\text { Height to crown } \\
\text { base (hcb) (m) }\end{array}$} & \multicolumn{2}{|c|}{$\begin{array}{l}\text { Stand basal } \\
\text { area }\left(\mathrm{m}^{2} / \mathrm{ha}\right)\end{array}$} & \multicolumn{2}{|c|}{$\begin{array}{l}\text { Crown } \\
\text { radius (m) }\end{array}$} \\
\hline & $\min$. & $\max$. & $\min$. & $\max$. & $\min$. & $\max$. & $\min$. & $\max$. & $\min$. & $\max$. \\
\hline Big leaf maple & 15.2 & 40.6 & 6.1 & 18.3 & 1.8 & 10.7 & 7.5 & 59.9 & 0.6 & 5.2 \\
\hline Blue oak & 15.2 & 94.0 & 3.0 & 56.1 & 1.2 & 24.4 & 4.5 & 76.1 & 0.6 & 7.6 \\
\hline Douglas fir & 15.2 & 137.2 & 4.9 & 57.3 & 0.0 & 30.2 & 0.9 & 80.2 & 0.3 & 8.5 \\
\hline Incense cedar & 15.2 & 147.3 & 4.0 & 59.1 & 0.9 & 27.4 & 2.0 & 90.4 & 0.6 & 7.0 \\
\hline Live oak & 15.2 & 68.6 & 4.6 & 15.2 & 1.2 & 7.9 & 12.5 & 61.1 & 0.6 & 4.0 \\
\hline Lodgepole pine & 15.2 & 48.3 & 8.2 & 34.1 & 2.7 & 21.3 & 3.6 & 51.1 & 0.6 & 4.0 \\
\hline 'Other conifers' & 15.2 & 58.4 & 5.5 & 53.0 & 0.9 & 18.6 & 1.1 & 55.1 & 0.6 & 4.6 \\
\hline 'Other hardwoods' & 15.2 & 50.8 & 4.6 & 25.9 & 0.3 & 10.7 & 8.6 & 78.2 & 1.2 & 4.6 \\
\hline Ponderosa pine & 15.2 & 106.7 & 6.1 & 55.8 & 0.6 & 28.7 & 0.9 & 79.6 & 0.3 & 7.9 \\
\hline Red fir & 15.2 & 149.9 & 4.9 & 53.9 & 0.0 & 28.3 & 0.7 & 110.8 & 0.6 & 5.5 \\
\hline Sugar pine & 15.2 & 132.1 & 6.1 & 59.1 & 0.0 & 30.2 & 1.3 & 88.3 & 0.6 & 9.1 \\
\hline White fir & 15.2 & 165.1 & 3.0 & 61.0 & 0.3 & 28.0 & 0.5 & 102.8 & 0.3 & 8.8 \\
\hline All trees & 15.2 & 165.1 & 3.0 & 61.0 & 0.0 & 30.2 & 0.5 & 110.8 & 0.3 & 9.1 \\
\hline
\end{tabular}

$\begin{array}{ll}\text { crrad } & : \text { quadratic mean crown radius }(\mathrm{m}) \\ \text { DBH } & : \text { diameter at breast height }(\mathrm{cm}) \\ \text { BA } & : \text { basal area per hectare }\left(\mathrm{m}^{2} / \text { hectare }\right) \\ \text { HCB } & : \text { height-to-crown base }(\mathrm{m}) \\ E & : \text { elevation }(\mathrm{m}) \\ b_{0}, b_{1}, b_{2} & : \text { regression coefficients }\end{array}$

DBH was used in all of the models because prior studies have reported that this is the most correlated variable with crown radius (e.g., Paine and Hann, 1982; Warbington and Levitan, 1992). Both DBH and crown radius are influenced in similar ways by many factors, such as a reduction in growth from increases in stand density. Basal area and number of trees were used as measures of stand density. However, we report only the results using basal area because the correlations of number of trees with crown radius are low for our data. These models were fitted separately for each species.

In addition to ordinary least squares, a weighted least squares (WLS) approach was used because we believed that there would be more variation (heteroscedasticity) in crown radius in larger trees than in smaller trees. The weights used in the WLS were $\left(1 / \mathrm{DBH}^{2}\right)$ or $(1 / \mathrm{DBH})$.

To test the influence of crown class on crown radius, regression analysis was performed using a dummy variable for grouped crown classes:
0 if crown class was dominant or codominant and 1 if crown class was intermediate or suppressed.

Crown classes were grouped because some classes had too few data points to adequately perform regression analysis. Using these dummy variables, intercept and slope shift terms were added to the linear and quadratic forms:

$$
\begin{aligned}
\operatorname{crrad}=b_{0}+b_{1} \mathrm{DBH}+\alpha_{0} Z & +\alpha_{1} \mathrm{DBH}^{*} Z \\
\operatorname{crad}=b_{0}+b_{1} \mathrm{DBH}+b_{2} \mathrm{BA} & +\alpha_{0} Z+\alpha_{1} \mathrm{DBH}^{*} Z \\
& +\alpha_{2} \mathrm{BA}^{*} Z \\
\operatorname{crrad}=b_{0}+b_{1} \mathrm{DBH}+b_{2} E & +\alpha_{0} Z+\alpha_{1} \mathrm{DBH}^{*} Z \\
& +\alpha_{2} E^{*} Z \\
\operatorname{crrad}=b_{0}+b_{1} \mathrm{DBH}+b_{2} \mathrm{HCB} & +\alpha_{0} Z+\alpha_{1} \mathrm{DBH}^{*} Z \\
& +\alpha_{2} \mathrm{HCB}^{*} Z \\
\operatorname{crrad}=b_{0}+b_{1} \mathrm{DBH}+b_{2} \mathrm{DBH}^{2} & +\alpha_{0} Z+\alpha_{1} \mathrm{DBH}^{*} Z \\
& +\alpha_{2} \mathrm{DBH}^{2 *} Z
\end{aligned}
$$

where

crrad : quadratic mean crown radius $(\mathrm{m})$

$Z \quad:$ the dummy variable for the crown

class defined above

DBH : diameter at breast height $(\mathrm{cm})$

HCB : height-to-crown base (m)

$b_{0}, b_{1}, b_{2}, \alpha_{0}, \quad:$ regression coefficients 
For each of the regression models using the dummy variable for crown class, an $F$-test (sometimes referred to as a Chow test) was performed to determine if this model was statistically significant over the model with the same independent variables, except without the dummy variable. For instance, $F$-tests were used to compare the model with DBH, BA, and the dummy variable to the model with $\mathrm{DBH}$ and $\mathrm{BA}$.

All the above regression equations were fitted to the model data and then used to predict crown radius for the test data sets. For the CR model data set, CR test, and cover data sets, $R^{2}$ and root mean square error (RMSE) were calculated. After all the regression equations were estimated, the 'best' model for each species was chosen. The best model form was selected by comparing $R^{2}$ and RMSE for each model, significance (at the $\alpha=0.05$ level) of the coefficients within the model, and the improvement in $R^{2}$ and RMSE over the model with DBH as the only independent variable.

\subsection{Canopy cover}

Using the predictions of crown radius (crrad), crown area $\left(\pi \mathrm{crrad}^{2}\right)$ was then estimated. This crown area was not necessarily the overall crown area of a tree since the crown radius models predicted the crown radius to the intersection of the crown of the adjacent tree. These estimates of crown area were then summed and divided by plot area to calculate predicted canopy cover.

For the 677 (0.04 ha) plots for which crown mapping was completed, non-overlapping canopy cover was calculated. $X Y$ coordinates of each tree were computed from the distance and azimuth from the plot center to the tree. The crown of each tree was assumed to be an ellipse, with the axes being the crown radii to the center of the plot and the crown radii perpendicular to that point. The area covered by all the trees on a plot was calculated using numerical methods and then converted to canopy cover percent by dividing by the plot area. ${ }^{4}$

Estimates derived from summing the crown area calculated using predicted crown radii were then compared to the canopy cover data collected using

\footnotetext{
${ }^{4}$ It was assumed that the amount of canopy falling out of the plot was equivalent to the amount being reflected into the plot from trees outside the plot boundaries.
}

crown mapping. Regression models were then developed with the actual canopy cover data (from crown mapping) as the dependent variable and the canopy cover predicted from the regression models as an independent variable. Additional independent variables representing stand density (basal area per hectare, trees per hectare (TPH)) were also considered because we believed that stand density influences canopy cover. The square of predicted canopy cover was also tested as an independent variable. In addition to linear regression models, several non-linear models were considered. Models with upper asymptotes were used because it is not possible for non-overlapping canopy cover to exceed $100 \%$. These models could then be used to calibrate the prediction to the actual canopy cover. Using the calibrated models in conjunction with the models of crown radius, it was possible to predict canopy cover from standard forest inventory variables.

\section{Results and discussion}

\subsection{Crown radius}

For the ordinary least squares (OLS) model without the dummy variable for crown class, there was only a slight improvement upon the addition of variables after the inclusion of DBH for the model data and both test data sets. Table 7 lists the $R^{2}$ and RMSE for the model with DBH as the only independent variable, and for some competing models. We considered a competitive model to be any model in which the reduction in RMSE was greater than $0.03 \mathrm{~m}(0.1 \mathrm{ft})$ for the model data set or either of the test data sets. $R^{2}$ for these models ranged from 0.2691 for the model with only DBH for the 'other conifers' to 0.6077 for the model with only DBH for sugar pine. For the two species, Douglas-fir and incense cedar, a competitive model was a quadratic equation with $\mathrm{DBH}$ as the independent variable. Residual plots from these models indicated no apparent heteroscedasticity. For the majority of the species, the model with only DBH appeared to be adequate. As DBH and crown radius would be influenced by competition from other trees in similar ways (i.e. competition would cause a reduction in individual tree growth, which would result in both smaller DBH and crown extension), it seemed 
Table 7

Table of fitted statistics for crown radius models

\begin{tabular}{|c|c|c|c|c|c|c|c|}
\hline \multirow[t]{2}{*}{ Species } & \multirow[t]{2}{*}{ Model } & \multicolumn{2}{|c|}{ CR model data } & \multicolumn{2}{|c|}{ CR test data } & \multicolumn{2}{|c|}{ Cover data } \\
\hline & & $R^{2}$ & RMSE & $R^{2}$ & RMSE & $R^{2}$ & RMSE \\
\hline Douglas fir & $b_{0}+b_{1} \mathrm{DBH}$ & 0.5085 & 0.9146 & 0.4957 & 0.9179 & 0.3790 & 0.7812 \\
\hline Douglas fir & $b_{0}+b_{1} \mathrm{DBH}+b_{2} \mathrm{DBH}^{2}$ & 0.5310 & 0.8935 & 0.5189 & 0.8965 & 0.4694 & 0.7222 \\
\hline Douglas fir ${ }^{\mathrm{a}}$ & $b_{0}+b_{1} \mathrm{DBH}+\alpha_{1} Z+\alpha_{2} Z(\mathrm{DBH})$ & 0.5147 & 0.9089 & 0.5016 & 0.9114 & 0.4628 & 0.7263 \\
\hline Red fir & $b_{0}+b_{1} \mathrm{DBH}$ & 0.4911 & 0.6512 & 0.5002 & 0.6094 & 0.5139 & 0.4963 \\
\hline White fir & $b_{0}+b_{1} \mathrm{DBH}$ & 0.4414 & 0.6081 & 0.4433 & 0.5928 & 0.3845 & 0.5634 \\
\hline Incense cedar & $b_{0}+b_{1} \mathrm{DBH}$ & 0.4161 & 0.7203 & 0.4279 & 0.6840 & 0.3187 & 0.5992 \\
\hline Incense cedar & $b_{0}+b_{1} \mathrm{DBH}+b_{2} \mathrm{DBH}^{2}$ & 0.4280 & 0.7130 & 0.4420 & 0.6757 & 0.4124 & 0.5567 \\
\hline Incense cedar ${ }^{\mathrm{a}}$ & $b_{0}+b_{1} \mathrm{DBH}+\alpha_{1} Z+\alpha_{2} \mathrm{Z}(\mathrm{DBH})$ & 0.4216 & 0.7171 & 0.4304 & 0.6822 & 0.3871 & 0.5678 \\
\hline Lodgepole pine & $b_{0}+b_{1} \mathrm{DBH}$ & 0.4202 & 0.7007 & 0.4086 & 0.5961 & 0.5676 & 0.4759 \\
\hline Lodgepole pine & $b_{0}+b_{1} \mathrm{DBH}+b_{2} \mathrm{HCB}$ & 0.4925 & 0.6584 & 0.4599 & 0.5735 & 0.4228 & 0.5634 \\
\hline Ponderosa pine & $b_{0}+b_{1} \mathrm{DBH}$ & 0.5651 & 0.6703 & 0.5596 & 0.6760 & 0.5244 & 0.6656 \\
\hline Sugar pine & $b_{0}+b_{1} \mathrm{DBH}$ & 0.6077 & 0.7984 & 0.6132 & 0.8016 & 0.6619 & 0.7588 \\
\hline Redwood & $b_{0}+b_{1} \mathrm{DBH}$ & 0.3530 & 0.9854 & 0.2691 & 1.0991 & NA & NA \\
\hline Old growth & $b_{0}+b_{1} \mathrm{DBH}$ & 0.1764 & 1.4897 & 0.1073 & 1.3944 & NA & NA \\
\hline Other conifers & $b_{0}+b_{1} \mathrm{DBH}$ & 0.2691 & 1.1389 & 0.4484 & 0.7362 & $<0$ & 0.9417 \\
\hline Other conifers & $b_{0}+b_{1} \mathrm{DBH}+b_{2} E$ & 0.3961 & 1.0397 & 0.4748 & 0.7231 & 0.31932 & 0.8280 \\
\hline
\end{tabular}

${ }^{\mathrm{a}}$ Species that are italicized have dummy variables in their model.

List of variables: $\mathrm{DBH}$, diameter at breast height; $\mathrm{HCB}$, height to crown base; and $Z \quad 0$ if crown class is dominant or codominant and 1 if crown class is intermediate or suppressed; $E$, elevation.

reasonable that DBH would be a good predictor of crown radius, as these results indicated. However, it was interesting that the inclusion of other variables, particularly some measure of stand density, had such a small impact on the predictive abilities of the models. This apparent lack of sensitivity to density may be a result of the fact that the data set has been collected primarily from managed forests. These forests have been treated over time to keep the average basal area and tree stocking in a narrower range than might occur in natural stands where fire suppression might allow higher densities to occur.

Even though heteroscedasticity was not apparent, a WLS approach was tried due to our concern that more variation existed in the crown radii of larger trees. The residual plots from the WLS models closely resembled those of the OLS models, and so we chose to use the simpler OLS models. It was surprising that there was nearly as much variation in crown radius of smaller DBH trees as found in larger DBH trees.

The models developed using the crown class dummy variable (0 if crown class was dominant or codominant and 1 if crown class was suppressed or intermediate) were statistically significant, based on $F$-tests, over the models without the crown class dummy variable for some species and some models fitted, but not for all species or all models. The model with the crown class dummy variable and DBH was statistically significant at the $\alpha=0.1$ level for Douglas-fir, incense cedar, ponderosa pine and white fir (refer to Table 8). Even though the model for ponderosa pine with the crown class dummy variable was significant, neither of the coefficients of the dummy variable were significant at the $\alpha=0.1$ level. For most of the models, significant or not, there were only minor improvements, as judged from reduction in RMSE or 
Table 8

Table of fitted statistics for significant models which included the dummy variable

\begin{tabular}{|c|c|c|c|c|c|c|c|c|c|}
\hline \multirow[t]{2}{*}{ Species } & \multicolumn{3}{|c|}{ CR model data set } & \multicolumn{3}{|c|}{ CR test data } & \multicolumn{3}{|c|}{ Cover data set } \\
\hline & $R^{2}$ & RMSE & $p$ value $^{\mathrm{a}}$ & $R^{2}$ & RMSE & $p$ value $^{\mathrm{a}}$ & $R^{2}$ & RMSE & $p$ value $^{\mathrm{a}}$ \\
\hline Douglas fir & 0.5147 & 0.9089 & $7.46 E 36$ & 0.5016 & 0.9114 & $6.90 E 19$ & 0.4628 & 0.7263 & $7.65 E 92$ \\
\hline Incense cedar & 0.4216 & 0.7171 & $4.11 E 06$ & 0.4304 & 0.6822 & 0.0096 & 0.3871 & 0.5678 & $2.64 E 25$ \\
\hline Ponderosa pine & 0.5678 & 0.6682 & $1.99 E 06$ & 0.5612 & 0.6745 & 0.00393 & 0.5506 & 0.6461 & $3.70 E 09$ \\
\hline White fir & 0.4421 & 0.6074 & $3.51 E 05$ & 0.4441 & 0.5993 & 0.02219 & 0.4049 & 0.5538 & $1.69 E 22$ \\
\hline
\end{tabular}

increase in $R^{2}$, over the model with DBH as the only independent variable. There were only two species (Douglas-fir and incense cedar) for which the reduction in RMSE over the model with only DBH was greater than $0.03 \mathrm{~m}(0.1 \mathrm{ft}$ ) (refer to Table 7$)$. Both species in which a model including crown class is judged to be a competitive model are considered intermediate in shade tolerance.

\subsection{Canopy cover}

Using the crown radius models with $\mathrm{DBH}$ as the only independent variable (refer to Table 9 for coefficients), canopy cover was estimated. After comparing these estimates of canopy cover to the crown mapped data of canopy cover, it was found that calibration was necessary. The 'best' linear regression model was the OLS model with modeled canopy cover, modeled cover squared, TPH and BA. Residual plots indicated that WLS was not warranted for the cover data. This model had an $R^{2}$ of 0.7495 and 0.6555 and an RMSE of 9.042 and 11.004 for the test and model data sets, respectively. With this model, it was possible to obtain predicted canopy cover of greater than $100 \%$. For this reason, non-linear models with asymptotes were also fitted. The best non-linear model was the "natural growth model' (Parton and Innes, 1972):

$$
\text { Actual cover }=a^{*}\left(1-e^{b^{*} \text { modeled cover }}\right)
$$

where $a$ and $b$ are coefficients of the model. In this model, the $a$ coefficient is the upper asymptote and the $b$ coefficient is the rate at which the function approaches the asymptote. Since the upper asymptote for canopy cover is $100 \%$, the $a$ coefficient was set to 100 prior to model fitting (the value of $a$ in an unconstrained model was 104.2 with a standard error of 10.7). This model had an $R^{2}$ of 0.721 and an RMSE of 9.51 for the model data set and an $R^{2}$ of 0.627 and an RMSE of 11.49 for the test data set. The estimate of the $b$ parameter is 0.0092 with a standard error of

Table 9

Table of coefficients for the crown radius models with DBH as the dependent variable (crrad $\left.b_{0}+b_{1} \mathrm{DBH}\right)$

\begin{tabular}{lllll}
\hline Species & $b_{0}$ & Standard error of $b_{0}$ & $b_{1}$ & Standard error of $b_{1}$ \\
\hline Douglas fir & 1.6654 & 0.0181 & 0.0355 & 0.0003 \\
Incense cedar & 1.2960 & 0.0301 & 0.0256 & 0.0005 \\
Lodgepole pine & 0.5230 & 0.1955 & 0.0440 & 0.0048 \\
'Other conifers' & 1.1817 & 0.2627 & 0.0265 & 0.0040 \\
Old growth & 2.5067 & 0.4123 & 0.0244 & 0.0032 \\
Ponderosa pine & 0.9488 & 0.0258 & 0.0356 & 0.0005 \\
Red fir & 1.0171 & 0.0465 & 0.0259 & 0.0007 \\
Redwood & 1.7371 & 0.1007 & 0.0311 & 0.0016 \\
Sugar pine & 0.9906 & 0.0372 & 0.0398 & 0.0006 \\
White fir & 1.2256 & 0.0167 & 0.0299 & 0.0003 \\
\hline
\end{tabular}


0.00015 . This model of actual cover versus predicted cover served to calibrate the predicted cover derived from summing crown area predicted from the crown radii models.

\section{Conclusions}

This study found that crown radii could be predicted from commonly measured tree variables. For the species modeled, the only predictor variable needed was DBH. Using calibrations applied to these crown radii models, it was possible to predict canopy cover from tree and stand variables that are commonly measured (DBH, TPH, and BA). In the absence of stem mapped data for calibration, photointerpretation of canopy cover could be used for calibration. These models can be used to predict canopy cover at one point in time or can be included in larger growth and yield models to predict canopy cover over time. Since canopy cover is an important indicator of wildlife habitat and is in fact part of CWHR, it is essential that it be predicted.

If inventory data exist, these models represent a fast and efficient method of estimating canopy cover and do not require additional field measurements. The alternative methods of estimating canopy cover are often time consuming (photointerpretation) and/or require additional measurements in the field (transects, crown mapping, and densiometers). However, as the standard error of prediction is approximately $10 \%$, these methods should be used for the classification of forest stands into relatively broad canopy cover classes, such as those used in the CWHR system. This suggested use (in classed canopy analysis) may allow the use of the simpler DBH only model forms. The potential of these forms to produce estimates of canopy greater than $100 \%$ is not relevant because the highest class minimum (usually $>60 \%$ or $>80 \%$ ) would include all higher values.

\section{Acknowledgements}

The authors would like to thank Dr. Richard P. Thompson and Dr. Eric C. Turnblom for their reviews of early versions of this manuscript. Also, we thank the anonymous reviewers for their considered reviews.
This research was funded partially by McIntire-Stennis project 6154-MS and by a California Polytechnic State University Faculty Development grant.

\section{References}

Avery, T.E., Burkart, H.E., 1994. Forest Measurements, 4th ed., McGraw Hill, New York, USA, 331 pp.

Biging, G.S., Dobbertin, M., 1992. A comparison of distance dependent competition measures for height and basal area growth of individual conifer trees. For. Sci. 38(3), 695720.

Biging, G.S., Dobbertin, M., 1995. Evaluation of competition indices in individual tree growth models. For. Sci. 41(2), 360 377.

Biging, G.S., Congalton, R.G., Murphy, E.C., 1991. A comparison of photointerpretation and ground measurements of forest structure. In: Proc. 56th annual meeting of the American Society of Photogrammetry and Remote Sensing, Baltimore, MD, vol. 3, pp. 615 .

Bunnel, F.L., Vales, D.J., 1989. Comparison of methods for estimating forest overstory cover: differences among techni ques. Can. J. For. Res. 20, 101107.

Burk, T.E., 1990. Prediction error evaluation: preliminary results. In: Wensel, L.C., Biging, G.S. (Eds.), 1990 Proc. IUFRO Conference on Forest Simulation Systems, November 1988, Berkeley, CA, University of California, Berkeley Bulletin 1927, pp. 8188 .

Congalton, R.G., Biging, G.S., 1992. How to validate stand maps. In: Proc. Stand Inventory Technologies '92 Conference, Portland, OR Am. Soc. for Photogrammetry and Remote Sensing, Bethesda, MD, USA, pp. 7482.

Cook, J.G., Stutzman, T.W., Bowers, C.W., Brenner, K.A., Irwin, L.L., 1995. Spherical densiometers produce biased estimates of forest canopy cover. Wildlife Soc. Bull. 23(4), 711717.

Daniels, R.F., Burkhart, H.E., Clason, T.R., 1986. A comparison of competition measures for predicting growth of Loblolly pine trees. Can. J. For. Res. 16, 12301237.

Eyre, F.H. (Ed.), 1980. Forest Cover Types of the United States and Canada, Society of American Foresters, Washington, DC, USA, 206 pp.

Farr, W.A., DeMars, D.J., Dealy, J.E., 1989. Height and crown width related to diameter for open grown western hemlock and Sitka spruce. Can. J. For. Res. 19, 12031207.

Goelz, J.C.G., 1996. Open grown crown radius of eleven bottom land hardwood species: prediction and use in assessing stocking. S. J. Appl. For. 20(3), 156161.

Mayer, K., Laudenslayer, W., Jr. (Eds.), 1988. A Guide to Wildlife Habitats of California, California Department of Forestry and Fire Protection, $166 \mathrm{pp}$.

O'Brien, R.A., 1989. Comparison of overstory canopy cover estimates on forest survey plots. Intermountain Research Station Research Paper N417, pp. 15.

Paine, D.P., 1981. Aerial Photography and Image Interpretation for Resource Management, Wiley, New York, USA, 571 pp. 
Paine, D.P., Hann, D.W., 1982. Maximum crown width equations for southwestern Oregon tree species. Research Paper No. 46, Oregon State University, Department of Forestry, Corvallis, 20 pp.

Parton, W., Innes, G., 1972. Some graphs and their functional forms. International Biological Program Grassland Biome Technical Report No. 153, Natural Resource Ecology Labora tory, Colorado State University, Fort Collins, CO, USA, 41 pp. Serra, J., 1982. Image Analysis and Mathematical Morphology, London Academic.

Uzoh, F., Ritchie, M.W., 1996. Crown area equations for 13 species of trees and shrubs in northern California and southwestern Oregon. Research Paper PSW RP 227, Pacific Southwest Research Station, 13 pp.

Vales, D.J., Bunnell, F.L., 1988. Comparison of methods for estimating forest overstory cover. I. Observer effects. Can. J. For. Res. 18, 606609.

Warbington, R., Levitan, J., 1992. How to estimate canopy cover using maximum crown width/DBH relationships. In: Proc. Stand Inventory Technologies '92 Conference, Portland, OR Am. Soc. for Photogrammetry and Remote Sensing, Bethesda, MD, USA, pp. 319328. 